\title{
The Lament of a Female Postgraduate PhD Student at a South African University: An Academic Wellness Perspective
}

\author{
Prof Meahabo Dinah Magano ${ }^{1}$ \\ ${ }^{1}$ Department of Inclusive Education, University of South Africa, South Africa \\ Correspondence: Prof Meahabo Dinah Magano, Department of Inclusive Education, University of South Africa, \\ South Africa. E-mail: maganmd@unisa.ac.za \\ Received: February 28, 2013 \\ Accepted: April 9, 2013 \\ Online Published: May 14, 2013 \\ doi:10.5430/ijhe.v2n2p211 \\ URL: http://dx.doi.org/10.5430/ijhe.v2n2p211
}

\begin{abstract}
The paper examines the case of a female doctoral candidate who studied over a period of eight years at a South African university and the challenges she encountered. It reports on a qualitative study that followed a narrative approach and employed a method known as the 'listening guide.' Findings revealed that the voluntary participant faced hardships, and her self-esteem, assertiveness and self-confidence changed from being positive to negative over the eight years. Change of supervisors contributed to her frustration but despite the negative experiences she remains positive and hopes that one day she will complete her PhD. Another positive aspect is that she has published articles based on her research in international journals.
\end{abstract}

Keywords: PhD student, Supervisors, Attitude, Collegiality, Personality

\section{Introduction}

Higher education is central to delivering the knowledge requirements for equipping professionals, producing new knowledge and contributing to economic and social development (Badsha \& Cloete, 2011). In producing new knowledge in higher education, academics are encouraged to conduct research and supervise master's and doctoral students. As an academic and graduate who studied through correspondence on a part-time basis I faced a plethora of challenges at postgraduate level, especially as an adult with a family. This is a common lament of many mature students in developing or partly-developed countries, especially first generation graduates. I was motivated to embark on this study by peers studying for doctorates who were in their late forties or fifties. In our informal discourses the topic extended to other factors, such as gender and ethnicity. I was persuaded to write the paper since I am in academia and supervising master's and doctoral students and wish to contribute to debates about pedagogy and supervision. The case study was intended to discourage those who wish to give up on their studies from doing so, and to answer the research question: What experiences led the PhD student to lament during her studies?

The South African government is concerned about the completion rate of master's and doctoral students enrolled at universities. In a longitudinal study tracking doctoral students in South African universities between 2000 and 2009 , institutions were ranked according to the rate at which they graduated doctoral candidates, with the high category managing to graduate $64 \%$ of their doctoral enrolments, as opposed to $43 \%$ for the medium group and $30 \%$ for the low producing group. The statistics give a clear indication that despite their best efforts the percentage remains low, with a growth rate of 4\% per annum (Centre for Higher Education Transformation (CHET), 2012). In order to develop a knowledge-based economy, positioned between developed and developing countries, the country will need to increase its $\mathrm{PhD}$ production rate by a factor of about five over the next 10 to 20 years (Department of Science and Technology (DST), 2008:28). The Department of Education (DoE) cohort study of the total first-time intake for year 2000 found that after five years only $30 \%$ of the students had graduated, $56 \%$ having left their original institution without graduating. The report further found that it was not possible accurately to track students who might have transferred to other institutions, but it was estimated at 10\%, whereas 14\% were still in the system (DST, 2008). A study conducted by the Academy of Science for South Africa (ASSAF) (2010) found that the average time taken to complete a $\mathrm{PhD}$ was 4 years 8 months, and only $26 \mathrm{PhD}$ graduates were produced per year for every million of the population. Following the low output rate of $\mathrm{PhD}$ graduates there is an initiative supporting a planned fivefold increase in the number of doctoral graduates by 2025 (MacGregor, 2009). Bearing in mind the above percentages, we focus on the contribution to them by black female mature students failing to complete their studies and the various reasons that hinder their progress. 


\subsection{Being a black female postgraduate in South Africa}

The journey of female doctoral candidates in general is characterised by a number of negative experiences, some of which are unavoidable and frustrating. For instance, as Leonard (1997) asserts, women are more likely to experience 'fractured' doctoral careers or studies because of the pressures of combining work and family, thus increasing the likelihood that when they do find time to study they will be of mature student status. From disadvantaged communities, most postgraduate students, especially at $\mathrm{PhD}$ level, are in their forties, still with work and family ties and having to enrol for a $\mathrm{PhD}$ on a part-time basis. Some are single parents without a partner to assist with children, others caring for AIDS orphans.

In black communities there are many social roles that women play, for instance assisting with catering for funerals and weddings, seldom for fewer than 600 people. This is a sign of ubuntu, a belief that one cannot live in isolation. Whether or not one is in academia one is part of, and expected to assist with, social events, or face discrimination. Although males attend the functions their involvement with manual work is limited to slaughtering a sheep or fetching ice for the drinks buckets.

\subsection{Completion rate of $P h D s$}

Worldwide, the completion rate for postgraduate students ranges from poor to abysmal (Lubbe , Worral \& Klopper, 2005). Depending on the conditions in which individuals find themselves the completion period will differ. Favourable circumstances and adequate support will enable one to complete within the stipulated period, but if conditions are not good or suitable for studying it will be prolonged or studies cancelled. Golde and Dore (2001) found that half of the students who enrol for postgraduate studies do not complete them and that $40 \%$ and $46 \%$ of postgraduate students respectively would have picked a different topic and supervisor if given the opportunity. Other problems with $\mathrm{PhD}$ completion emanated from insufficient knowledge of the relevant field, change of supervisors due to transfer to another institution, lack of supervisory support and supervisor's other workload (Wadesango \& Machingambi, 2011).

Lack of in interest in the topic and/or a poor relationship between student and supervisor are important factors for any research student, and if there is an area which is not driving the study in the right direction then the $\mathrm{PhD}$ is stalled. Extended candidature in postgraduate studies affects the resources available per student (Wamala, Ocaya \& Oonyu, 2012), and the financial implications of retaining PhD students at an institution beyond the stipulated three-year period is perceived by some scholars as a waste of resources. However, this latter issue depends on a number of issues, particularly the circumstances of the student.

Lessing and Lessing (2004) include amongst general aspects that influence graduate completion rate the extent to which the degree programme is student friendly, accessibility of administrative procedures, understanding of academic and scientific requirements, ability to judge workload related to different components of the research process, retention of the supervisor, contact with the supervisor, and overcoming isolation. Obstacles related to these aspects may hinder the progress of a student if not dealt with at an early stage of the research. The student and the administrative personnel, librarian, supervisor and the research process are the main components of the $\mathrm{PhD}$ journey, and none of these should be overlooked.

\subsection{Supervisor and supervisee relation}

Seagram, Gould and Pyke (1998) regard the relationship with supervisors as a key factor in study success. The postgraduate student requires supervision and support in order to produce research that is of good quality, thus the relationship between supervisor and supervisee determines the way in which it will be driven. A study of Southern Africa and the supervisor-supervisee relationship among postgraduates identified as major obstacles: delays, lack of schedule for meetings, lack of records of discussions, supervisors being too busy to meet students, and heavy teaching loads (Mutula, 2009). Manathunga (2007) sees supervision as mentoring, and if regarded as such by both parties then the issue of power will be dealt with amicably. The student relates to the supervisor from the position of a mentee and learns from the process, unlike the more traditional master/apprentice model (Manathunga \& Goozee, 2007), in which there was usually a power struggle (Ganqa, 2012).

In exercising power in supervision, the relationship may also be strained by words used in feedback messages. In a study conducted by Wadesango and Machingambi (2011) findings revealed that $75 \%$ of respondents were dissatisfied with their supervisor's feedback on research work. Whilst feedback should be constructive, the student must be ready and willing to take criticism in a positive spirit. Kumar and Stracke (2007), in their analysis of written feedback on a $\mathrm{PhD}$ thesis, suggest that the interaction between the supervisor and the supervisee played an important role in the induction of the supervisee into the academic community. Feedback should provide a form of teaching and an ethos of care, not as pampering but as guidance, providing the necessary support and allowing the doctoral candidate to assume a natural identity by encouraging passion for and interest in the studies. 


\subsection{The Psychological and emotional experiences of PhD students}

A study conducted by Guilfoyle (2006) revealed that the culture of some students prohibits them from expressing their views to supervisors, even when dissatisfied. The inability to have freedom of expression in meetings with supervisors often causes frustrations and as a result they resort to turning to other students who may be in similar predicaments to discuss their problems. The cultural background of not expressing one's views to authorities disadvantages the student and without assistance from peers may lead to psychological disturbances. Some students may develop emotional and social blocks which are not shared with the supervisor or peers (Ahern \& Manathunga, 2004). Magano (2011) argues that supervisors should encourage forums of postgraduate students, or indabas, in which candidates can deliberate on issues that trouble them. Communication is necessary between supervisor and students to alleviate frustration and black females should be assertive, irrespective of, perhaps because of, any cultural, gender or ethnic differences between them and the supervisor.

Other emotional and psychological disturbances during one's study may emanate from family issues, revealed by Ingleton and Cadman (2002) as including the personal and financial cost of competition, the weight of responsibility towards family, and the need to maintain a successful self-image. Unfortunately, the study revealed that these issues were not shared but kept secret. Silence on such crucial psychological and emotional issues were not known to supervisors and failure to express them resulted in an inability to cope with academic responsibilities. Some students are reluctant to admit to an inability to cope, in line with recent research by Giddens (1991) and Scheff (1997), the latter describing shame as the emotion basic to the dynamics of relationships, with pride accompanying solidarity and shame accompanying alienation. Emotions play an important role in building a successful academic self-identity.

In South Africa, the University of KwaZulu-Natal conducted a study using a cohort Model of supervision (Govender \& Dhunpath, 2011), following a group of supervisors in workshops with $\mathrm{PhD}$ students interacting amongst themselves. They found that when students being supervised by different supervisors attend workshops together they benefit from contributions offered by peers and are guided through the various phases in the research process.

Sweitzer (2009) writes that students' personal communities are important in providing support other than that form the supervisor, for instance from individuals not associated with the academic programme. Such social networks enhance the coping skills of the doctoral students. during a period of studying. The studies pointed out clearly indicates that the academic life is not in isolation to one's psychological, emotional and social well-being. The theoretical framework in the subsequent paragraph will outline a lens for the current study.

\section{Theoretical Framework}

I used the wellness model as a lens for the study, defined by Tager (1988) as a deliberate and conscious effort to optimise rather than normalise all areas of life, including, but not restricted to, health, attitudes, happiness, productivity, love and physical fitness. Wellness is understood as a person's total approach towards improving the quality of life, health and psychological strengths, in proactive and positive ways, both as member of a community and as an adult (Witmer \& Sweeney, 1992). Wellness is viewed as an integrated method of functioning which is orientated towards maximising the individual's potential (Myers \& Williard, 2003). Similarly, Ardell (2003) maintains that wellness is a proactive approach to life that optimises one's potential, whilst for Myers, Sweeney and Witner (2000, p.252) it is "a way of life orientated toward optimal health and well-being in which body, mind and spirit are integrated by the individual to live life more fully within the human and natural community". In using the wellness model I was able to look at the academic wellness of the participant and other dimensions, such as emotional, spiritual, social and career wellness from Hetler's model (1980). Ideally, it is the optimum state of health and well-being that each individual is capable of achieving. Hetler's wellness model was developed to promote student wellness within higher education and is in agreement with other models in terms of the conceptualisation of wellness and its dimensions. Intellectual wellness (Note 1) encourages creative, stimulating mental activities and is about the continuing acquisition, further development and creative application of independent and critical thinking skills, as well as openness to new ideas. An intellectually well person uses the available intellectual and cultural activities and resources to expand his/her knowledge and to improve skills.

Although there will be challenges on the way, Hetler (1984) believes these can be used as steppingstones. Bearing in mind this positivist perspective, for the current study on the lament of a postgraduate student, the intellectual wellness remained relevant as I looked at how the PhD student was trying to expand her knowledge and improve skills from her master's degree by studying further. Although the focus of the study and the lens used was mainly intellectual wellness, other wellness dimensions inter-relate with intellectual wellness. The study revealed how the participant's emotional, spiritual, psychological, social and career wellness were bound together in her PhD journey. 


\section{Research Design}

The study is located under the constructivist-interpretive paradigm and a discursive qualitative approach (Henning, Van Rensburg \& Smit, 2004). A narrative approach outlined by Clandinin and Connely (2000) was used in order to record the experiences of the participant, a more feasible way of collecting data than asking individual questions which might not have elicited some of her experiences. I verified the question or request which best suited the narrative research, as "Please relate your journey of your PhD study from enrolment to where you are currently." This was uncomplicated and to the point, giving time for the participant to answer and for me to listen. The next steps were for the participant to relate her life experiences and the context of the story, for me to reorganise the story, then for both of us to negotiate relationships, in this case the meaning of the stories as interwoven so that the researcher gained insight into her own life (Clandinin \& Connely, 2000). In this study purposive sampling was used since I targeted only one participant, a lecturer at the university. She had studied for her BA, BEd and MEd degrees part time, and in all had managed to complete within the stipulated time span. However, for her $\mathrm{PhD}$ she had exceeded the time limit. The reason for targeting the participant was due to the duration of study being eight years, which was beyond that stipulated for a $\mathrm{PhD}$, and still without indication that she might complete her study in that year.

I observed all ethical considerations and permission was granted to conduct the study. The participant signed the consent form and was assured of anonymity and respect for human rights. An interview was used to collect data and I audio-taped the narration. I allowed her to take her time, sometimes stopping and sighing deeply before continuing to narrate. I applied what Henning et al. (2004) suggest by using interjections such as "hmm... sjo... eish.." to encourage her and make explicit my interest in what she was narrating. An interview lasted for an hour.

\section{Data Analysis}

Creswell (2009:183) defines data analysis as a process that involves making sense out of text and image data. It means the researcher moves deeper into understanding the data and making an interpretation of its wider meaning. Narrative research involves 're-storying' the participant's story using structural devices, such as plot, setting, activities, climax and denouement (Clandidnin \& Connely, 2000). The current study followed an approach by Gilligan, Spencer, Weinberg and Bertsch (2006), known as the 'listening guide method,' which is one of the emergent methods in social research used by cultural psychologists and psychological anthropologists, though mainly used by feminists to show their concerns about the ways in which a person's voice can be covered by that of the researcher, and their caution against voicing over the truth of another.

The following extract is a transcript of the narrative from the female $\mathrm{PhD}$ female student who was interviewed. A pseudonym is used to cover her real identity.

\section{Extract of Moipone}

I have never been humiliated like this in my entire life but this PhD is really a thorn in my flesh...hai. In all my degrees from BA, BEd and master's I did not struggle to complete and my lecturers and my masters' degree supervisor commended me on my work. To give you a clear picture of my PhD journey let me say I registered in two thousand and four in this university where I am employed as a lecturer. I thought I would take three years at the most since I am working here. My topic was interesting and I am the one who decided on it. I had two supervisors, who were understanding and their personality was fine. After a year I was requested to join a major project for the faculty and I dropped the topic that I loved the most. After joining that major project I changed supervisors and the topic changed also. What attracted me was the funding in this new project and I was promised overseas trips and free books. The topic allocated to me was also interesting so I did not mind to start again. Indeed I got trips to go overseas and got developed in many areas of how to conduct research. Initially with my supervisors it was interesting and I enjoyed their guidance. My supervisors were both females and were scholars who were respected. My main supervisor was a thorough person and very knowledgeable in the field. She gave me more books to read and I also read more articles in order to be grounded in the theory. My chapter one was fine and both supervisors were happy. When I started with my chapter two of literature review that is where problems started. My main supervisor started to send me nasty feedback which was in a way undermining me. She was my colleague and I did not expect that kind of treatment. I did not confront her regarding nasty remarks but it was painful. The other supervisor was not so actively involved in my study and I doubt if she ever read my work. Even though my main supervisor was not happy with my chapter two, she allowed me anyway to proceed to the chapter of research methods. She said we will go back to that chapter when we are done with the findings. I collected data and there were even artefacts that I collected to support my study. I send evidence to my supervisors of what I did in the research design and still I received feedback from only one supervisor and the other one was quiet still. I received 
feedback and still there were discouraging remarks but I did corrections accordingly and sent back to her. I took a long time transcribing data since I had many participants. After analysing data using an advanced qualitative data analysis method I submitted the chapter and comments were also negative. My supervisor wrote the following words which nearly destroyed me "... you don't show any academic development." She was not happy with that chapter but she said we will go back to it when we are done with other chapters. I continued to interpret data and discuss findings but none of the chapters were satisfactory and complete according to my supervisor. It was now the fifth year then my supervisor started to be abusive in her feedback and I started to take it personally, moreover we were people from two different races and knowing the history of South Africa of the apartheid regime and how blacks were oppressed, the comments were creating a serious rift between us. My co-supervisor was passive, she never marked my work all along though I was also sending her work. I started to cry alone and did not know where to go for help, but I continued to send my work to my supervisors. When the university administration cautioned me that I was taking too long and was not registering any progress, I thought my supervisors would defend me, but to my surprise they were aloof and they were actually saying negative things about my academic development, though at this stage I had already analysed data. My main supervisor lied and said that I do not send my work and is naïve of my progress. These allegations prompted that there should be a hearing and I brought the evidence that I have been submitting and the data that I collected. My supervisor apologised in front of seniors and we continued though the relationship was now strained. She felt that I tarnished her image by telling the truth. The following year was my sixth year of study, my main supervisor resigned from her post and was appointed at another university and I was allocated another new main supervisor though my co-supervisor was still there co-supervising. The new main supervisor wanted me to change a number of things, I became obedient and tried to follow instructions and suggestions. Amongst these changes I was instructed to re-analyse my data, which I did, and presented findings which were similar to initial findings. My new supervisor was impressed and I also regained confidence. I thought this was a new beginning and maybe I would finish my PhD in my sixth year. That year came to an end and no chapter was declared complete or being in good shape. In my seventh year of study I was told that there would be yet another co-supervisor, meaning that I would have three supervisors. This is a year when I felt that my work was stalled deliberately. I followed instructions, I submitted timeously. My third new supervisor wanted my work from chapter one so that he could follow the content. It was as though I am starting from scratch, I was so disillusioned I did not have the energy to submit chapter by chapter. It was as though I am starting my PhD all over again. Some days I would cry and feel stupid, worthless and those words of my previous supervisor would ring in my ears "... you do not develop academically..." My new supervisor would mark language only and not comment on the content. My main supervisor would suggest some readings that I have included without going through the contents of my chapters. When I reply to her emails and indicate that I have read those articles and cited them she would apologise. I really felt discouraged and I was so demotivated and thought of going to another university, but the thought of starting again made me to abandon that idea. What killed my self-esteem was when I attended doctoral seminars of students who started years after me and I felt so dumb. I asked my main supervisor about my doctoral seminar and she said they need to get the examiners first then I can think about that. My main supervisor was avoiding using words which would destroy me, instead she avoided remarking or writing anything negative. In my eighth year of study I was told to change the theoretical framework by my main supervisor so that I can follow what she sees fit for my study. I told her that this was not going to be possible for me since this would influence my data collection methods and data analysis. I resisted and convinced myself that I was on the right track. My third new co-supervisor did not comment on my response to refusing to change my theoretical framework, neither did my main supervisor respond. There was silence and there was no more guidance on what to do next, it was a stalemate. After a period of a month or so of silence I terminated the silence by sending my entire work from chapter one up to the end to all my supervisors. As usual the third one marked grammar throughout, my co-supervisor was silent as usual and my main supervisor came from another angle, and she wrote "your chapter on literature shows that you have read and I am impressed, you included a lot, just reduce it and have half of what you wrote." This nearly destroyed me when I think of reducing half and throwing it away. I asked myself this question, why did she not suggest that all along that I should reduce my literature review? I am currently trying to reduce and I asked again whether it will be possible to give a presentation for my final doctoral seminar. The answer was negative and my main supervisor said I am not yet ready to present my work. This disturbed me, I cried and some co-workers were suggesting that they can help me shape my work. I really feel worthless, my self-esteem is low and if one completes his or her PhD, to me is like an arrow piercing through my heart. I feel that academia is not for me I am even scared to write a piece of work and show it to colleagues. I spend sleepless nights crying and my pillow is always wet. I am so stressed I gained weight since I use food as pain relief measure. I am no longer attending social gatherings like weddings and family functions and church services, since I told my closest friends and relatives that I am busy with my PhD and I want to finish. I am compelled to attend funerals since those I cannot avoid. I avoid the company of people that know that I am studying 
because they always ask me this question... "when are you graduating?" I reply by saying that I am still busy and give excuses. Being a married woman, mother, lecturer and a member of society comes with certain demands, therefore it is not easy to finish PhD. After saying those words I would cry inwardly go to the toilet and cry so that no one can notice. Some of my friends call me a doctor already and I feel that they are mocking me and when I am alone I cry. Instead of having joy that one day I will complete and have a doctoral degree I feel the pain in my heart. I am lamenting over the change of my first supervisors and topic. I lament the loss of time.

\section{Findings}

The listening guide method that I used in data analysis had four steps and the findings for this study are presented according to these, as follows:

\section{Step 1.Listening for the plot}

In listening for the plot, Gilligan, Spencer, Weinberg and Bertsh (2006) point out that one is drawing out the essence of the narrative by looking at the territory, what is happening, when, where, with whom and why. In this study I looked at the participant's experience and what the lament was about. The territory is a university at which the participant is studying, and also her place of employment. She is supervised by her colleagues. In looking through the lens used for this study of intellectual wellness, Moipone's wellness is affected in the sense that her academic wellness is not isolated from other wellness dimensions. The social, spiritual and physical aspects are also affected, since wellness dimensions cannot be separated in a person's holistic wellness. In interpreting the 'when' this marks a period of study of eight years, still with no indication as to when the participant will complete. The 'where' is depicted by the study and work environment that constantly bring pain when other $\mathrm{PhD}$ students are presenting their seminars.

The 'with whom' is clearly shown in the entire narration, that it is Moipone with different supervisors. The main supervisors are the main role players throughout the journey of Moipone and all co-supervisors are silent, though one tried to mark only language. The challenge of Moipone is having supervisors who change, and with them the style.

The 'why' was answered mainly by the lived experience of Moipone on her $\mathrm{PhD}$ journey. Her challenge lay in the degree being stalled, the change of supervisors and the approach. The change of the initial supervisors was a major cause of lament.

The participant's narration depicts a person who was confident at the beginning of her PhD journey but as the tears show, her studies and nights seem to be the time to lament, when no one sees.

\section{Step 2. I poems}

In analysing the narrative one looks at the use of the first person, 'I', and how the narrator speaks about himself or herself (Gilligan et al., 2006, p.259). One needs to select the verbs accompanying the 'I'. A poem is built using phrases spoken by the narrator on different lines. These 'I poems' must be written in stanza forms and reflect a shift in meaning or change in voice.

\section{Moipone's I poem}

I have never been humiliated like this...

I did not struggle to complete...

I thought I would take three years...

I had two supervisors...

The I poem of Moipone starts by depicting a negative feeling of humiliation, whereas in the inception of her study she had hoped to finish in three years. It appears the participant had not struggled in her previous degrees, but the $\mathrm{PhD}$ was stalling and she felt that it brought humiliation to her.

I was requested to join a major project...

I dropped the topic that I loved...

I changed supervisors... topic changed...

I was promised overseas trips...

I did not mind to start again...

I got trips to go overseas...

I enjoyed their guidance... 
The above stanza shows a positive spirit that Moipone did not mind changing the topic and supervisors since some positive rewards had been promised, such as overseas trips and funding. The participant enjoyed the new supervision and the new topic was not a problem to her. In line 2 she dropped the topic that she loved.

I started chapter two... problems started...

I did not expect that...

I did not confront her...

I doubt...

I send evidence...

I received feedback from only one...

In analysing the above stanza of Mopione's I poem, one notices the onset of problems, though not at the stage of the lament. In her frustration there is fear of confronting the supervisor regarding the nasty feedback. What concerned Moipone was that she doubted if the co-supervisor had ever marked her work, due to the silence and her having only received feedback from one supervisor.

I started to take it personally...

I started to cry...

I thought my supervisor would defend me...

I do not send my work and is naïve of my progress...

I brought the evidence...

I tarnished her image...

The above stanza shows an emotional pain that Moipone experienced, and the crying marks the beginning of tears leading to a lament. There was also an expectation of support from supervisors when the administration was querying the duration of study, but instead of support the supervisor denied that the student had sent work. This was disappointing to Moipone and she was saved only by the evidence of emails. The relationship was somehow spoilt and the supervisor felt that her image had been tarnished.

I was allocated another new main supervisor...

I became obedient...

I was instructed to re-analyse my data...

I regained confidence...

I thought this was a new beginning...

I would finish my PhD in my sixth year...

The above stanza shows a situation which had potential to discourage Moipone, but she was obedient and re-analysed data. She was able to see a new beginning for her $\mathrm{PhD}$ and hoped to finish in her sixth year of study.

I was told that there would be yet another supervisor...

I felt that my work was stalled deliberately...

Ifollowed instructions...

She was experiencing yet more frustration at having a new supervisor, and she arrived at a conclusion that her work was being stalled deliberately.

I am starting from scratch...

I was so disillusioned...

I did not have the energy to submit chapter by chapter...

I would cry and feel stupid...

I really felt discouraged and demotivated...

This shows how despondent Moipone was, and disillusion characterised by lack of energy to re-submit chapters. Tears were now a common phenomenon in the life of the participant, made more sad by her feeling stupid. The question arises as to whether she felt stupid because of not completing or because she was now crying whenever an 
issue arose from her $\mathrm{PhD}$ work. There was discouragement and de-motivation, which were not going to bring positive results for the $\mathrm{PhD}$ journey.

I attended doctoral seminars...

Ifelt so dumb...

I was told to change my Theoretical framework...

I told her... not possible ...

I resisted and convinced myself...

I was on the right track...

The participant felt stupid after attending doctoral seminars in which other doctoral candidates were presenting their work. The irony is that instead of gaining courage that she would also one day present her work she felt stupid. In this stanza one realises a change of attitude or response, as she received an instruction to change the theoretical framework. She resisted, determined to stick to her original thought. One also notices the stance that she took and the conviction that she was on the right track.

I terminated the silence...

I think of reducing half...

I am currently trying to reduce...

'I am not yet ready to present my work...'

I cried...

I really feel worthless...

Ifeel that academia is not for me...

I am even scared to write...

I spent sleepless nights crying...

I am so stressed...

I gained weight...

I am no longer attending social gatherings...

The above stanza is a clear indication that the participant is in distress and pain. When she was told that she was not ready to present her work that brought devastation. There is also a clear picture of a life characterised by tears and a feeling of worthlessness. She was scared to write and was spending sleepless nights crying. Due to stress, that is negative, Moipone laments that she had gained weight due to using food for pain relief. Moipone was scared of attending social gatherings, where people would ask about her PhD. This is a picture of a lifestyle that is lost and characterised by grief. Moipone laments for her PhD and not being able to face society and tell them that she is completing or will complete her $\mathrm{PhD}$. The study is also affecting her wellness dimensions, not only intellectual but also physical. The stress affects her emotionally and spiritually, and in overeating her physical wellness is also affected.

I avoid the company of those...

I give excuses...

I would cry inwardly...

I feel that they are mocking me...

I am lamenting over the change of ...supervisors

I lament the loss of time

Due to the period extending to eight years, Moipone tried by all means to avoid the company of those people who know her. She was no longer attending functions and gave excuses. When people were complementing those who had completed their doctoral degrees she felt that she was being mocked. In front of people Moipone would cry inwardly, which I interpret as wearing a mask and pretending to be strong. She tried not to show people that she was crying inwardly but she finally pointed out that she was lamenting over the change of supervisors and time. To Moipone there was pain, grief and regret as to why the supervisors had been changed. 


\section{Step 3. Listening for contrapuntal voices}

In The New Webster's Dictionary of the English Language (1972) 'contrapuntal' means 'counterpoint' or 'the opposite in meaning.' Gilligan et al. (2006) write that in this step one listens to the counterpoint in the text and the research question of the study is also important at this stage. The research question in this study is: What experiences led the PhD student to lament during her study period? In the I poems Moipone pointed out that she did not struggle to complete her previous degrees, which is a positive statement, but later said 'I felt so dumb'. These are contradictory statements uttered by the participant about her intellectual wellness. She was confident about her cognitive ability but as years elapsed she felt as though she were not clever. Another contrapuntal voice is seen when the participant mentioned how she enjoyed the supervision of the first supervisors, but later says: 'I was so disillusioned'. Moipone did not confront the second pair of supervisors when problems started but later she had the courage to refuse instruction silently, as evident when she says 'I resisted and convinced myself I was on the right track'. The participant would regain confidence but then the opposite would happen, as she said 'I really felt discouraged and demotivated'. In answering the research question I can say the change of initial supervisors, the time taken, lack of progress on the $\mathrm{PhD}$ study, and the negative feedback received from different supervisors, all caused the participant to lament.

\section{Step 4. Composing an analysis}

In the final step of the listening guide, Gilligan et al. (2006) recommend that the researcher pull together what has been learned about the participant in relation to the research question. Moipone's voice reveals frustration throughout the narration. Her challenges began the moment her supervisors and her topic changed. Her voice clearly shows that she feels worthless, humiliated and reluctant to meet even people she knows. What is worse is that she is scared to write, which is actually what she needs to do to complete her $\mathrm{PhD}$. The tears of Moipone are not visible to her acquaintances since she cried inwardly. These are not ordinary tears but Moipone is using a deeper or strong word which is 'lament.' There is loss, which is experienced here and causes the participant to lament the loss of time, the absence of joy in studying, fear of meeting friends, and lack of peaceful sleep. What is encouraging is that she is not giving up on her $\mathrm{PhD}$. I argue that the participant was not respected as a colleague and her abilities were often undermined. My argument is supported by the words used when feedback was given to Moipone, such as 'you don't show any academic development,' which are a deterrent. The feedback brought fear to Moipone of writing other pieces of work, and her self-worth was also compromised. Written feedback allows the student to engage in critical thinking and writing (Kumar \& Stracke, 2007). The student will be able to accept criticism positively if the relationship between the supervisor and supervisee is positive.

For the participant the initial supervision did not bring problems but the change of supervisors and nasty remarks spoiled the relationship and feedback was perceived negatively. Moipone's attitude changed, which blocked any further guidance from the supervisors. Written feedback is a powerful tool in postgraduate supervision, as it can be directive, guiding the student by giving suggestions and constructive comments (Kumar \& Stracke, 2007). However, for Moipone it was destructive and discouraging, especially with the second set and third set of supervisors. The participant did perceive suggestions as directive and constructive. The main cause of the lament in this case was the change of initial supervisors, which she enjoyed, their supervision and her moment of studying under it.

\section{Conclusion}

The study may be concluded by highlighting that female postgraduate students who are of mature age have a number of challenges that characterise their journey of studying. What is positive about the mature age cohort is that they know what they want in life, have set clear goals and are determined to achieve those goals. The participant in this study had managed to complete her pervious degrees within the stipulated period of study, studying on a part-time basis. When one looks at the issue of supervision and relationship between student and supervisor it appears as though it is the central issue around the journey of Moipone's studies. The participant was supervised by her colleagues at the university where she was also employed as a lecturer. The issue of collegiality is overlooked.

The relationship between supervisor and supervisee also influences the manner in which feedback will be taken. Since feedback is embedded in supervisory relationships (Kumar \& Stracke, 2007) the participant and her relationship with the second and third pair of supervisors was tarnished by nasty words used, and also the manner in which her work was stalled. The negative feedback brought fear to Moipone, as seen in her utterances as: 'I am even scared to write'. The participant's self-worth was also compromised, hence my thesis is that Moipone's intellectual wellness was somehow affected negatively.

Another important element in postgraduate supervision that emerged is the issue of duration of study. The participant is currently in her eighth year but the chapter which appears to be ready is only one chapter, since problems started with chapter two. The question which one may ask is: is the study being stalled or not? The duration of study has cost implications and also the participant's well-being is affected. By personalising what is written in feedback, the 
participant's attitude and well-being were negatively affected. Regarding Moipone's wellness, not only the intellectual is affected but other dimensions, such as emotional, social and physical. Emotionally she started to cry and was disillusioned; socially she started to avoid gatherings or the company of people she knew; physically she gained weight as she used food for pain relief. The time taken for the $\mathrm{PhD}$ is daunting and one wonders whether together with the third pair of supervisors the study will be brought to completion. One positive element is that although she is lamenting she is resilient and continues her studying.

The mentoring relationship in this study is characterised by lack of support and negativity. Though the participant and her supervisors were colleagues it appears as though there is a hierarchical tradition in the form of supervision. Moipone remains voiceless in some instances and does not confront or ask questions where she was dissatisfied. In mentoring there is support and trust, as Manathunga (2007) puts it, and in effective supervision, where there is mentoring there is a contribution to producing timely research student completions. In this study, in a period of eight years, the study was still not completed, hence the mentoring was not effective or the mentee was not willing to be guided. The philosophy and rationale behind mentoring is that the mentor is wiser and more experienced than those they mentor, and can share knowledge with mentees (Manathunga, 2007). The current study revealed hostility, since there was no collaboration or interaction as collegial equals, especially with the second and third set of supervisors. The unfortunate part is that she is now lamenting and the relationship is not good between her and the supervisors. Instead of the study bringing joy to the participant it has brought tears. She is persisting and hopefully will complete one day.

I recommend that postgraduate students who are of mature age should be able to balance their academic and social life so that they can attain the goals they set before embarking on their journey of studying. In Higher Education, there is still a need for supervision at postgraduate level. Issues of hegemony should be dealt with and an ethos of support and care promoted. Professional boundaries around the work-based supervision relationship should be created, whereby colleagues respect each other and mentoring pedagogy takes place harmoniously. Students also should be open-minded about criticism and reflect on what they write and be willing to correct. By reflecting on one's work, learning through self-regulation is promoted. Of importance is that students find supervisors whom they trust and get along with before they start. I recommend that one supervisor is better and students may change if they do not feel that the relationship of mentor-mentee is working. I strongly recommend that students do not have colleagues as supervisors and study at a different institution from the one in which they are employed. Crying and moaning does not help, rather any postgraduate student who is frustrated should seek psychological counselling.

Further research may be conducted on a larger sample, in particular on students who take long to complete their $\mathrm{PhDs}$, to find out how their wellness is impacted.

\section{References}

Ahern K. \& Manathunga C. (2004). Clutch-starting stalled research students. Innovative Higher Education, 28,4, 273-254. [Online] Available: http://escape.library.uq.edu.au/view/UQ:71670

Badsha, N. \& Cloete, N. (2011). Higher Education Contribution for the NPC's National Development Plan. Center for Higher Education Transformation.

Cadman, K. (2000). 'Voices in the air" Evaluations of the learning experiences of international postgraduates and their supervisors, Teaching in Higher Education, 5,4,475-491. [Online] Available: www.aare.edu.au/00pap/ing00194.htm

Center for Higher Education and Transformation (2012). Reflecting on South Africa's PhD output ambitions 13 March 2012 P1.

Clandinin, D.J. \& Connely, F.M. (2000). Narrative inquiry: Experience and story in qualitative research. San Francisco: Jossey-Bass.

Department of Science and Technology. (2008). Ten year Plan for Science and Technology.

GanqaN.H. (2012). Supervision Experiences of Masters in Education Students at a South African University. Unpublished Masters Dissertation University of Fort Hare.

Giddens, A. (1991). Modernity and Self-Identity. Self and Society in the Late Modern Age. United Kingdom: Polity Press Cambridge.

Gilligan, C., Spencer, R. Weinberg, M.C. \& Bertsch, T. (2006). Emergent methods in Social Research. London: Sage.

Golde, C.M.\& Dore, T.M. (2001). At Cross Purposes: What the experiences of today's doctoral Students reveal about doctoral education. Philadelphia, PA: A report prepared for The Pew Charitable Trusts. 
Guilfoyle, A. (2006). Peers, family, community, supervisors and governance: A review of key sites for supporting international postgraduate students' transitional learning experience. [Online] Available: http://Isn.curtin.edu.aultlf2006/referenced/guilfoyle.html

Hetler, B. (1980). Wellness promotion on a university campus. Family and Community Health, 3, 77-95. http://dx.doi.org/10.1097/00003727-198005000-00008

Hetler, B. (1984). Wellness: encouraging a lifetime pursuit excellence. Health Values, 84, 7-13.

Ingleton, C. \& Cadman K. (2002). Silent issues for international postgraduate research students: Emotion and agency in academic success. The Australian Educational Researcher, 29, 1, 93-113. http://dx.doi.org/10.1007/BF03219771

Kumar, V. \& Stracke, E. (2007). An analysis of written feedback on a PhD thesis. Teaching in Higher Education, 12 , 4, 461-470. [Online] Available: Cluteonline.com/journals/index.php/TLC/article/...128/125

Leonard, D. (1997). 'Gender Issues in Doctoral Studies'. In Graves N. and Varma, V. (eds) Working for a Doctorate: a Guide for the Humanities and Social Sciences. London: Routledge. 152-183

Lessing, M. Lessing, A.C. (2004). The supervision of research for dissertation and thesis, Acta Commercial, 4,73-79.

Lubbe S. Worral, L. \& Klopper, R. (2005). Challenges in Postgraduate Research: How Doctorates Come off the Rails. Alternation, 12, 1, 243-262. [Online] Available: Uir.unisa.ac.za/handle/10500/3008

MacGregor, K. (2009). South Africa: Push to graduate more PhDs. University World News, 31 May 2009 issue 30.

Magano, M.D. (2011). The Social and Emotional Challenges of female Postgraduate Students in South Africa. Journal of Social Sciences, 29,3, 205-212. [Online] Available: www.uj.ac.za/EN/Faculties/edu

Manathunga, C. \& Goozee, J. (2007). Challenging the dual assumption of the 'always/already' autonomous student and effective supervisor. Teaching in Higher Education, 12, 3, 309-322. http://dx.doi.org/10.1080/13562510701278658

Manathunga, C. (2007). Supervising as mentoring: The role of power and boundary crossing. Studies in Continuing Education, 29, 2, 207-221. http://dx.doi.org/10.1080/01580370701424650

Mutula S.M. (2009). Challenges of Postgraduate Research : Global context, African Perspectives. Key note Address delivered at the University of Zululand, 10 ${ }^{\text {th }}$ DLIS Annual Conference, from 9-10 September 2009.

Myers, J.E. \& Williard, K. (2003). Integrating spirituality into counseling and counselor training: A developmental, $\begin{array}{lllll}\text { wellness approach. } \quad \text { Counselling and } & \text { 142-155. }\end{array}$ http://dx.doi.org/10.1002/j.2161-007X.2003.tb00231.x

Myers, J.E., Sweeney, T.J. \& Witmer, J.M. (2000). The Wheel of Wellness counseling for wellness: A holistic model for treatment planning. Journal of Counselling and Development, 78, 251-266. [Online] Available: http://libres.uncg.edu/ir/uncg/listing.aspx?id=4498

Scheff, T. (1997). Emotions, the Social bond, and human reality: part/whole analysis. Cambridge: Cambridge University Press. http://dx.doi.org/10.1017/CBO9780511549496

Seagram, B., Gould, J., \& Pyke, S. (1998). An investigation of gender and other variables on time to completion of doctoral degrees. Research in Higher Education, 39, 3, 319-335. http://dx.doi.org/10.1023/A:1018781118312

Sweitzer, V.B. (2009). Towards a Theory of Doctoral Student. Professional I dentity Developed: A developmental Network Approach. The Journal of Higher Education, 80, 1, 1-33. http://dx.doi.org/10.1353/jhe.0.0034

The New Webster's Dictionary of the English Language. (1972). International Edition Lexicon International. New York: Publishers Guild Group.

Wadesango, N. Machingambi, J. (2011). Postgraduate Students' Experiences with Research Supervisors. Journal of Sociology and Anthropology 2,1,31-37. [Online] Available: www.ccsenet.org/journal/index.php/hes/article

Wamala, R. Ocaya, B. \& Oonyu J.C. (2012). Extended Canditure and Non-completion of a PhD at Makerere University, Uganda.

Witmer, J.M. \& Sweeney, T.J. (1992). A holistic model for wellness and prevention over the lifespan. Journal of Counselling and Development, 71,140-148. http://dx.doi.org/10.1002/j.1556-6676.1992.tb02189.x

\section{Notes}

Note 1 . The terms intellectual wellness and academic wellness were used interchangeably in the study. 